\title{
Chapter 8 \\ The Triangle-Lady and Billy Goats Gruff: Constituting Contents for Learning in Play
}

In this chapter, we study how contents for learning emerge in play. From a didaktik perspective, it is of interest not only to highlight what contents are constituted and how but also how these contents may be appropriated by children in play. Building on the premise that communication is the mechanism of learning, how participants communicate in and about play become critical to our analysis.

Our analysis aims at clarifying how content for learning is constituted in play and particularly in communication in and about the play, regardless of whether the contents are introduced into the activity through the child's or the teacher's initiative. There are many studies reporting, for example, what features of mathematics can be made into contents for learning in different activities (e.g., Bäckman, 2015; Björklund, 2007; Lundström, 2015). However, in the analysis of the present chapter, we highlight contents that actually become the nexus of shared attention and exploration in different ways. Of particular interest to our analysis is what are necessary knowledge or skills for participants to develop in order to be able to continue their interaction and play (see also Chap. 10 about conceptual resources necessary for play).

As already mentioned, we are here interested in what contents are constituted in the analyzed activities and how the children indicate that they start appropriating these (i.e., actualized cultural tools and practices). We present the analysis in two sections, corresponding to different ways contents are constituted in play: (1) External content for learning introduced into play, including (a) Isolated content for learning, and (b) Learning content necessary for play. These contents are characterized by being introduced by the teacher, with different aims. However, we also see content emerging in the interaction between teacher and children in play: (2) Learning contents emerging in play. This second category is qualitatively differentiated into: (a) Learning the framework of the play, (b) Learning how to play, and (c) Developing concepts as part of the play. 


\section{External Content for Learning Introduced into Play}

In our observations of teachers participating in children's play, teachers implement content for learning that are of both academic character and concerns social skills. What stands out is that the teacher takes on the role of introducing the content to the children, but as it turns out, this content can remain isolated from the children's play, or the content is considered necessary for the children to embrace in order to play (on).

\section{Isolated Content of Learning}

An isolated content for learning can be found when the teacher asks a specific question or gives the child a task to solve, where it is apparent that a particular answer is expected. The function of asking this kind of question thus is to make sure children have sufficient knowledge of some predefined content.

When it comes to language learning (i.e., writing and reading) and mathematics learning, teachers readily see opportunities to count or spell. However, the content for learning, which is quite distinct to both an observer and participating children, may remain isolated and does not refer to, or is not integrated with, the play. Phrased differently, the content is not sufficiently recontextualized to the play.

\section{Excerpt 8.1a: Billy Goats Gruff}

\begin{tabular}{l|l|l}
\hline 1 & CIA: & $\begin{array}{l}\text { Once upon a time there were three goats and they all were named (inaudible) (with } \\
\text { a dramatic voice) }\end{array}$ \\
\hline 2 & Lisa: & Gruff \\
\hline 3 & $\begin{array}{l}\text { Two } \\
\text { children: }\end{array}$ & $\begin{array}{l}\text { I'm the middlest. I'm the bigglest [in Swedish: Jag är den mellande (mellan). Jag } \\
\text { ar } \text { den } \text { (stora) }\end{array}$ \\
\hline 4 & Kalle: & I'm the smallest \\
\hline 5 & Lisa: & No, I'm the smallest \\
\hline 6 & Child: & Here, beneath, here beneath is the troll \\
\hline 7 & CIA: & Yes, but are there three trolls also (with a dramatic voice)? \\
\hline 8 & Child: & I'm troll \\
\hline
\end{tabular}

In this initial sequence, the teacher and the children negotiate about which roles to play in a well-known story. There are opportunities opened up for topicalizing mathematical concepts for size and order, which are central parts of the story and notions the children are familiar with, albeit here not using the conventional words (turn 3). The teacher does not respond to this didaktikal opportunity; instead, she directs the children's attention to an occurrence outside the story they are initiating: 


\section{Excerpt 8.1b: K for K-N-I-F-E}

\begin{tabular}{l|l|l}
\hline 9 & Child: & But look, look here (creeps in under the bench) \\
\hline 10 & CIA: & Oh, where shall it be? But what is it? \\
\hline 11 & Peter: & It's for the letter wall (has something in his hand) \\
\hline 12 & CIA: & What is it? A...? \\
\hline 13 & Child: & Knife \\
\hline 14 & CIA: & Which letter does it being with? \\
\hline 15 & Child: & T \\
\hline 16 & CIA: & You think so? T K K K \\
\hline 17 & Child: & Knife \\
\hline 18 & CIA: & K K K \\
\hline 19 & Child: & K \\
\hline 20 & CIA: & Yes \\
\hline 21 & Nils: & Three can be, three can be, and three can also be trolls. \\
\hline
\end{tabular}

The sequence represented in this excerpt shows how an occurrence that leads the participants' attention outside their ongoing play becomes content for learning. The sounding of " $\mathrm{K}$ " has no relevance to their play, but the children follow the teacher in this excursion. However, one child (Nils) makes an effort to bring back the focus to the play they had initiated in the first place (turn 21). He does so, through, in a sense, recontextualizing "three" (letters) to three trolls, relevant to the story.

Mostly, in this kind of occurrences, where the teacher introduces a learning content while participating in a play situation, the children have already developed the skills necessary for solving the task and it can be questioned whether any opportunity to learn anything qualitatively new is offered the children. Furthermore, this approach is in a sense counter to, rather than responsive to, children's play.

\section{Learning Content Necessary for Play}

To participate in play, one needs some knowledge of the framework, roles and actions that are relevant. Usually, this is negotiated between the play participants. Sometimes the teacher adds a new item, feature or notion into the activity, which may alter the play-frame and either disrupts the play (similarly to in the previously presented category) or is incorporated into evolving play. These then have the potentials of working as contents for learning (since they may not be known before by all the participants) that are necessary for the development of mutual play.

The following excerpt seems at first glance to be the teacher attempting to introduce an isolated mathematical content into a child's play; quite typical for how mathematical contents are presented and dealt with as contents of learning in preschool (see e.g., Björklund, Magnusson, \& Palmér, 2018). The teacher asks for permission to join the child's play, she takes on a role that makes her a participant 
in the play and she introduces the content, in this case mathematical shapes, but the shapes do not at first appear to have any connection to what the child is playing (a part of this activity was analyzed with a different focus in Excerpt 5.7):

\section{Excerpt 8.2a: The Triangle-Lady is Visiting}

\begin{tabular}{l|l|l}
\hline 7. & GUNN: & You're playing in the hut. May I pop in? \\
\hline 8. & Siri: & Yes \\
\hline 9. & GUNN: & I take a look here. Oh! What a NIIICE hut you've made \\
\hline 10. & Siri: & And I have lots of pets. Here! \\
\hline 11. & GUNN: & Do you have so many pets? \\
\hline 12. & Siri: & Yes, a whole box full! \\
\hline 13. & GUNN: & $\begin{array}{l}\text { A box full of animals. Oh! Okay. But Siri, I thought that now when I come and } \\
\text { pay you a visit here in the hut I feel like playing with these for a while. Come and } \\
\text { take a look }\end{array}$ \\
\hline 14. & GUNN: & $\begin{array}{l}\text { I thought we would take these (gets up and gets a can) Oh it's such a } \\
\text { BEAUTIFUL hut. THESE, what do you think of THESE? What do you say we } \\
\text { play with these for a while? }\end{array}$ \\
\hline 16. & GUNN: & We can play that I come and visit you and then I'm the Triangle-Lady perhaps? \\
\hline 17. & Siri: & YES! \\
\hline 18. & GUNN: & $\begin{array}{l}\text { Should we do that? Is that okay? Can't you sit here next to me instead? Nice. The } \\
\text { Triangle-Lady comes and pays a visit (showing the triangle she holds in her hand) } \\
\text { Do you know why they're called triangle? }\end{array}$ \\
\hline 19. & Siri: & $\begin{array}{l}\text { 'Cause... they are a bit like that... (makes a drawing in the air with her finger) } \\
\text { They're almost like this! }\end{array}$ \\
\hline 20. & GUNN: & Yes, I agree \\
\hline 21. & Siri: & I actuallly have a book with shapes \\
\hline 22. & GUNN: & Shapes? \\
\hline 23. & Siri: & Yes, it's about Barbapapa \\
\hline 24. & GUNN: & Barbapapa. Can he make himself into shapes? \\
\hline 25. & Siri: & Yes \\
\hline 26. & GUNN: & Can he make himself into a shape like this? \\
\hline 27. & Siri: & Yes \\
\hline 28. & GUNN: & Aha. How many corners does it have? \\
\hline 29. & Siri: & ..three! \\
\hline 30. & GUNN: & $\begin{array}{l}\text { Three, yes. It can be called three-angle also [in Swedish, trekant (literally } \\
\text { three-angle) is a less formal word for triangle (Swedish: triangel)] }\end{array}$ \\
\hline 31. & Siri: & $\begin{array}{l}\text { Yes, and a nicer word for four-angle [in Swedish, fyrkant (literally four-angle) is a } \\
\text { less formal word for square] is square! }\end{array}$ \\
\hline
\end{tabular}

In this exchange, the teacher introduces a character that changes the direction of the activity. The participants (i.e., teacher and child) to some extent coordinate, what from a Vygotskian perspective could be referred to scientific concepts with everyday concepts (turns 18-19 and 28-31). It is the child who here (in turn 31) introduces a new mathematical/scientific term; and the teacher follows this up, 
which is not the most frequent unfolding of communicative events we see in the play activities we have analyzed.

\section{Excerpt 8.2b: What is a Better Name for...?}

\begin{tabular}{l|l|l}
\hline 32. & GUNN: & $\begin{array}{l}\text { Oh, what you know. Do you find a... what was it called again, four-angle, here in } \\
\text { the tub. THERE. What was a nicer word? }\end{array}$ \\
\hline 33. & Siri: & Square \\
\hline 34. & GUNN: & $\begin{array}{l}\text { Square was the nicer one. It was a difficult word, S Q U A R E [in Swedish: K V } \\
\text { A D R A T] and is there a nicer word for this (holds a triangle) }\end{array}$ \\
\hline 35. & Siri: & Rectangle? \\
\hline 36. & GUNN: & $\begin{array}{l}\text { Mmmm... almost right. TRIANGLE, THREE-ANGLE [cf. turn 30] (points out } \\
\text { the three corners) }\end{array}$ \\
\hline 37. & Siri: & YES \\
\hline 38. & GUNN: & $\begin{array}{l}\text { Three corners. One, two, three. Three-angle and triangle. How well you know. } \\
\text { What shall we build then when we build? }\end{array}$ \\
\hline 39. & Siri: & Shall we build a castle? \\
\hline 40. & GUNN: & Yees. Who should live in the castle? \\
\hline 41. & Siri: & $\begin{array}{l}\text { Ehhh Muss... we would need hundreds of pieces if we were to build a house for } \\
\text { Musse. }\end{array}$ \\
\hline 42. & GUNN: & Why? \\
\hline 43. & Siri: & 'Cause he's so big \\
\hline 44. & GUNN: & Yes, okay
\end{tabular}

The sequence represented in this excerpt is interesting for didaktikal development in three ways. First, the content is handled in a way that directs the child's attention to the attributes of the mathematical shapes, helping her to differentiate not only that there are different shapes with different names; they are different due to their specific features (number of sides and vertex). In this activity, it is not only the teacher who initiates new terms; in turn 31 and again in turn 33, we can see that the child provides a mathematical term for a shape: "square", to which the teacher responds by asking the child to find such a shape among the different ones in the bowl. Second, an aspect with an interest in didaktik is that this example of mathematics teaching is isolated from the child's self-initiated play, to which the teacher asked permission to participate. The geometrical objects are handled by the teacher as content for learning and in the communication between teacher and child, specific features of the shapes that distinguish a square from a triangle are made into a figure. However, the features of geometrical shapes do not contribute to the child's original construction play. That is, the content introduced is not coordinated with the play into which it is introduced, and in effect transforms the play into non-play. Nevertheless, the dialogue about shapes and their features and names returns in the continuing interaction and is eventually included in the play. This constitutes a third and not to be neglected aspect of didaktik: to introduce new content and visualize aspects of the world that the child might not have been able to recognize on her own, and that subsequently will contribute also to the development of the child's play: 


\section{Excerpt 8.3a: Musse's House}

\begin{tabular}{l|l|l}
\hline 64. & GUNN: & Yes, of course, of course. But how do we do with Musse's house here now? \\
\hline 65. & Siri: & That's fine \\
\hline 66. & GUNN: & Do you think he fits into this? \\
\hline 67. & Siri: & (with a tricky look, smiles) Nooo \\
\hline 68. & GUNN: & Noo (smiles) We'll have to make it a bit larger. Here's more squares \\
\hline 69. & Siri: & He needs a bit thicker house also \\
\hline 70. & GUNN: & Do you know any more nice words? \\
\hline 71. & Siri: & Oval \\
\hline 72. & GUNN: & OVAL!? What does an oval look like? \\
\hline 73. & Siri: & It's like a plateau, like this (draws with her finger in the air) \\
\hline 74. & GUNN: & Hm how? I'll have to try (draws with her finger in the air) How did you do? \\
\hline 75. & Siri: & They are... eeh... you should see, if only I brought my book \\
\hline 76. & GUNN: & $\begin{array}{l}\text { Is there any that looks... aha, the shapes book. Can't you bring it tomorrow? It's } \\
\text { really fun with shapes. }\end{array}$ \\
\hline 77. & Siri: & Of course I can! I can put it in my jacket pocket \\
\hline 78. & GUNN: & Yes, so you'll remember it \\
\hline 79. & Siri: & Yees. \\
\hline 80. & GUNN: & But can you tell me what is oval in shape, so that I understand what is oval? \\
\hline 81. & Siri: & $\begin{array}{l}\text { Eeeh... it's like soap that lies down, which is slimy, a little bit like... a jellyfish } \\
\text { (makes a gesture) but... slimier }\end{array}$ \\
\hline 82. & GUNN: & Yees... so the soap is like an oval? \\
\hline 83. & Siri: & Yes, the soap itself \\
\hline 84. & GUNN: & $\begin{array}{l}\text { Okay, then I think I understand what the shape oval is. I wonder why there are } \\
\text { shapes. Linn, do you know? }\end{array}$ \\
\hline & &
\end{tabular}

This section of the activity illustrates how the child is able to show some of her knowing; as is known from other studies (e.g., Magnusson \& Pramling, 2017; Pramling \& Wallerstedt, 2009), children often say that 'it's like this' (cf. turn 73) and then they show through gesturing or bodily enactment. However, in the nature of educational institutions such as preschool (and school), teachers often challenge children to try to go beyond showing to also telling (or explaining) (ibid.). To go from, and to coordinate, what one shows with what one says, constitutes an important general ability, critical to schooling. Challenged by the teacher to explain what an oval is, the child uses a number of similes (turn 81). From the child's reasoning it is not entirely clear what features of, in this case, a soap and a jellyfish she understands are shared with the geometrical shape of oval. At first, it appears that she intends the shape to be shared between a soap and an oval, but when suggesting that it is like a jellyfish, only a little more slimy (turn 81), she attends to another feature, and one not shared by an oval as such. Still, her explanation is ambiguous, as evident in her reasoning in this way at the same time as using meta-markers such as "a little bit like" (turn 81). It is possible that she here plays rather than provides a straightforward explanation of how she understands what an oval is. The content is introduced by the teacher and some of the concepts are challenging for the child to 
comprehend and express her understanding of. The child needs both to differentiate between what aspects are relevant to the concept and what are incidental to it (the shape 'oval' versus the texture 'slimy') and how to express this meaning (in words and gestures).

The question of why there are shapes (turn 84) seems to puzzle the child, since she does not respond to it. This kind of question is what Piaget (1926/1951) in the beginning of his research asked children, for trying to see if they could reason in terms of more formal logic. The inherent ambiguity of such questions are analyzed in Pramling and Säljö (2015). They argue that there can be many answers to a question such as what different forms can be used for, but why they exist is far more complex to answer. It is not entirely clear what an adequate answer would be. In the excerpt, the child responds to the situation by returning her attention to her book and her construction play:

\section{Excerpt: 8.3b: Shapes}

\begin{tabular}{|c|c|c|}
\hline 85. & Siri: & $\begin{array}{l}\text { Nooo, that's not what the book is about. It was the shapes. Eeh... how it } \\
\text { BECOMES }\end{array}$ \\
\hline 86. & GUNN: & You should learn how shapes become? \\
\hline 87. & Siri: & $\begin{array}{l}\text { Yes, for example... (stands up and shows on the hut) this becomes... eh... one } \\
\text { like these (picks up a square). This hut is shaped like one of these! }\end{array}$ \\
\hline 88. & GUNN: & Like a square. Yes \\
\hline 89. & Siri: & YES, look! (stands up and points around the edges of the hut) \\
\hline 90. & GUNN: & Yes, exactly. I think I understand. You have a square hut \\
\hline 91. & Siri: & YES \\
\hline 92. & GUNN: & Do you know what I'm doing now Linn? \\
\hline 93. & Siri: & No \\
\hline 94. & GUNN: & $\begin{array}{l}\text { Now I make a new shape, and this shape you said before (has shaped a } \\
\text { rectangular shape from the squares) }\end{array}$ \\
\hline 95. & Siri: & RECTANGLE \\
\hline 96. & GUNN: & $\begin{array}{l}\text { So much you know! Now let's see if you know this tricky one: What is the } \\
\text { difference between a square (Swedish: fyrkant [four-angle]) and a rectangle? }\end{array}$ \\
\hline 97. & Siri: & $\begin{array}{l}\text { A square has EQUALLY long sides, but this one... eh... one side is a bit longer } \\
\text { than the other. So this is a bit thinner (shows on the short side of the shape) than } \\
\text { this (shows the long side) }\end{array}$ \\
\hline 98. & GUNN: & $\begin{array}{l}\text { Okay, so two sides are a little shorter and two sides are a little... yes, EXACTLY! } \\
\text { RECTANGLE (nods). Excellent! Can Musse fit into this now (points at the } \\
\text { constructed rectangle)? }\end{array}$ \\
\hline 99. & Siri: & Yees \\
\hline
\end{tabular}

The teacher reformulates what the child shows into a conventional term, "a square" (turn 88). In this way, she coordinates the child's perspective and an institutional category (scientific concept). The child then refers to the book she mentioned earlier, and what information about the topic shapes that the book provides, namely, how shapes are made. She gives the example of the playhouse she has built (turns 87 and 89 ). The teacher then picks up on the idea of how to make shapes and con- 
struct a rectangle (turn 94) out of two squares, which is eventually reconnected with the original play theme about Musse (turn 98). The teacher and child are going in and out of the play (as if and as is), sometimes discussing specific content to develop their common understanding of (turn 97), which is then used within their mutual play frame (turn 98). This example shows how new content that is elaborated in conceptually developing ways later becomes a part in the child's subsequent play. That is, what is introduced by the teacher in a rather a-contextual way (vis-à-vis the child's ongoing play) is later recontextualized in terms of the play.

Another content for learning in play emerges when there are some necessary skills or knowledge that the child needs to acquire in order to participate and act in accordance with the play rules. This is shown in Excerpt 8.4, where a group of children and a teacher plan how to play Ninjas and Ninjagos (popular hero figures at the time of the observation):

\section{Excerpt 8.4: How to Play Ninja}

\begin{tabular}{|c|c|c|}
\hline 14. & CIA: & $\begin{array}{l}\text { But Amos and Nils, look here at Valter. What is it, what is it Valter, Valter tries to } \\
\text { tell here? }\end{array}$ \\
\hline 15. & Valter: & Yes, look at Olle and me \\
\hline 16. & CIA: & Yes, look at Olle and Valter now! \\
\hline 17. & Valter: & You shouldn't have bandy-sticks \\
\hline 18. & Valter: & That you hold like this \\
\hline 19. & CIA: & Hold like this (shows how she holds her hands together) \\
\hline 20. & Olle: & And then... and then... \\
\hline 21. & Valter: & Yes, it's a bit difficult when you, I have my mittens on \\
\hline 22. & Olle: & $\begin{array}{l}\text { Yees, and like, you do like this... (both boys show how they do sword-fighting } \\
\text { movements in the air. They make a swooshing sound while swinging their } \\
\text { imaginary swords) }\end{array}$ \\
\hline 23. & Olle: & And that's that... (returns to the group of children, several children start talking) \\
\hline 24. & Child: & $\begin{array}{l}\text { Ninjas, ninjas, they do like this... they sit like this (makes himself small) but } \\
\text { they sit like this... then they do like this and then they fight (show fighting with } \\
\text { his hands) }\end{array}$ \\
\hline 25. & CIA: & $\begin{array}{l}\text { Okay! But Valter, is is, is it an imaginary sword you mean? A bit like this, you } \\
\text { pretend to have a sword in fantasy? }\end{array}$ \\
\hline 26. & Valter: & Aah \\
\hline 27. & CIA: & $\begin{array}{l}\text { Do you remember that we made a fantasy journey before, we saw a waterfall } \\
\text { and so (makes movements with her hand) }\end{array}$ \\
\hline 28. & Children: & Aaa \\
\hline 29. & CIA: & $\begin{array}{l}\text { Just like that I think Valter is trying to tell with, with, kind of, fantasy sword. For } \\
\text { example like this now (gets up to a kneeling position and start fighting in the } \\
\text { air). Now I pretend... (makes sounds while swinging her imaginary sword). Did } \\
\text { you see how many I ninjad [Swedish: ninjade] down with my sword!? I'm a } \\
\text { super-ninja. (One of the children gets up and runs with a bandy-stick, holding it } \\
\text { as if it were a rifle. Makes shooting sounds.) }\end{array}$ \\
\hline 30. & CIA: & But ninjas without sword? Shall we see if we can do that? \\
\hline 31. & Child: & $\begin{array}{l}\text { But ninjas don't have swords, they do like this (shows how he hits and kicks in } \\
\text { the air, and then on a tree) }\end{array}$ \\
\hline 32. & Child: & But hello, ninjas are fencing at night and days all the time! \\
\hline
\end{tabular}


The imaginary fight seems to be troublesome to grasp for some of the children. The teacher picks up on this challenge, seeing it as a content for learning that is important in preparation for being able to participate in this kind of play. She refers to an activity they did earlier, where a waterfall was visualized with hand movements and sound (turn 27). In a similar manner, she addresses the suggested imaginary sword fight that some children tried to explain, by using her body movements and voice to illustrate her being a fighting ninja (turn 29). The content for learning here emerging is how to use one's body to gestalt (i.e., represent) imaginary actions. The skill of pretend fighting without a physical prop (a pivot; Vygotsky, 1978) is an important content that enables the children to participate in the play, and a content of importance to the teacher, who introduced the need of rules for the ninja play, in that no bandy sticks should be used as fighting tools towards another person (picked up by Valter in turn 17). That is, without being allowed to use some kind of physical props as swords, the children face the challenge of how to gestalt sword fighting only with their bodies (embodiment and sound-making). To be able to do so becomes a prerequisite for being able to participate in the play. Making the children pay attention to what a child does, in terms of verbalizing his embodied action in terms of "tell" (turn 14) and the rule that physical sticks cannot be used for fighting, the teacher triggers collaborative consideration of how to give gestalt to a critical part of the play with other means (as if having swords).

Another example of content for learning that turns out to be preparatory for play is shown in a catch-and-run play. There are no predefined general rules to the game and the teacher and the children have to make up the rules and roles. They do this within the frames of an imaginary sea world and the suggestions given make up the rules for the play. The content for learning is complex in this example, but concerns exploring "what sharks can do", something that is part of the framework of what kind of movements that are allowed in the play:

\section{Excerpt 8.5: Sharks in the Sea}

\begin{tabular}{l|l|l}
\hline 1 & Tom: & Sharks cannot be on, walk on land \\
\hline 2 & STINA: & $\begin{array}{l}\text { Sharks cannot be on land? How lucky then that we have water here (turns towards } \\
\text { the other children and points at the blue blanket) }\end{array}$ \\
\hline 3 & Adam: & They can swim like this (shows with his body how sharks swim) \\
\hline 4 & STINA: & $\begin{array}{l}\text { And they can swim like that and they can swim like this and that (showing } \\
\text { different ways to swim, while the children swim along on the blanket) }\end{array}$ \\
\hline 5 & STINA: & What else can sharks do (she sits up, the children stop swimming) \\
\hline 6 & Tom: & Sharks (stands and looks on)? \\
\hline 7 & STINA: & Yes \\
\hline 8 & Tom: & They can swallow a human whole \\
\hline 9 & STINA: & $\begin{array}{l}\text { Can they swallow a whole human being? You can come here and be shark (waves } \\
\text { for Tom to come). Come here and be a shark! (waves. Tom comes and sits down } \\
\text { on the blue blanket) What else can you be in water? }\end{array}$ \\
\hline 10 & Ewa: & Mermaid \\
\hline 11 & STINA: & And what do you say? (turns to one of the boys) \\
\hline
\end{tabular}




\begin{tabular}{l|l|l}
\hline 12 & Adam: & Eat meat ... \\
\hline 13 & STINA: & What do we do now then? \\
\hline 14 & Adam: & Let's do again! Then we can do again! \\
\hline
\end{tabular}

In this catch-and-run play, the teacher and children need to establish the rules for playing. They do this by showing and trying out different suggestions. Knowledge, such as introduced by Tom (turn 1), that sharks need water (as is), has decisive consequences for the emerging play rules: they have to move in a swimming mode and cannot enter and chase someone on land.

Common to the examples of contents of learning we here discuss is that they concern what is needed in order to participate in a particular kind of play. The teacher has a prominent role in offering different contents for the children to explore. The teacher works in all these examples in ways where she makes the framework explicit to the children and explains (with embodiment coordinated with words) what they mean and how to execute the necessary skills and knowledge. This means that the content for learning is extended in meaning to some children and works as confirmation to other children. In this way, both novice and expert players may be included in the same play.

\section{Learning Contents Emerging in Play}

In contrast to the play situations where the teacher initiates contents to be explored, we find another approach where the content for learning emerges within play. This category is further analytically differentiated into: Learning the framework of the play, learning how to play, and developing concepts as part of the play.

\section{Learning the Framework of the Play}

We can see that learning opportunities are plenty in play, but what, so to speak, is learning necessary for in these activities? What content is constituted and for what purpose? In some forms of play, such as "house" or "school", where the play participants take on certain roles (parent, sibling, teacher, postman) the content of learning is not only how to play that character but also in a sense the whole of the play (how to act and interact with the other characters of the play): how to play house or how to be at the doctor's to get a shot.

The younger children are more commonly invited by the teachers into structured play, such as rhymes or songs that traditionally follow a certain pattern of actions or movements. The following excerpt is of a play framed by a song about an egg, which is hidden under a cloth, and when the song comes to the end, a chicken comes out from under the cloth after a verbal cue: "come out" (Swedish: "Kom fram"). The child Karin in the excerpt is 2 years old. 


\section{Excerpt 8.6a: Hiding Chicken}

\begin{tabular}{l|l|l}
\hline 26. & Karin: & Hide (puts the chicken under the cloth). \\
\hline 27. & SARAH: & Should it be there? (puts her hand on the cloth) \\
\hline 28. & Karin: & Yes (nods) \\
\hline 29. & SARAH: & (sings) the chicken in the egg, the chicken in the egg sleep... \\
\hline 30. & Karin: & What \\
\hline 31. & SARAH: & (continues singing) what are you doing, are you sleeping? \\
\hline
\end{tabular}

The teacher accidently starts saying the wrong word "sleeping" (turn 29) and the child is immediately correcting her by saying the right word "what" (turn 30). This indicates that the child knows the song very well even though she is not singing along in this episode.

\section{Excerpt 8.6b: Counting for Closure}

32. Karin: (takes out the chicken from under the cloth and shows it to the teacher)

33. SARAH: No but, it was, beep beep chicken! (accepts the chicken Karin gives her)

34. Karin: Beep beep. Hide egg, hide egg (puts an egg under the cloth)

35. SARAH: Hide egg?

36. Karin: Yes

37. SARAH: One, two, three (folds up her thumb, index finger and middle finger for respective word)

38. Karin: (makes pointing movements up and down with her index finger in time with the teacher's counting, says simultaneously with the teacher) three

The teacher here introduces a new aspect to the play frame in that she counts "one, two, three", showing one, two and three raised fingers for each counting word (turn 37). The child immediately follows up on the teacher's initiative (turn 38).

\section{Excerpt 8.6c: Singing and Counting}

\begin{tabular}{l|l|l}
\hline 39. & SARAH: & (sings) chicken in the egg, chicken in the egg... come out! \\
\hline 40. & Karin: & (quickly pulls the egg from under the cloth, says something inaudible) \\
\hline 41. & SARAH: & (shows the chicken she has in her hand) beep beep \\
\hline 42. & Karin: & (hides the chicken under the cloth) \\
\hline 43. & SARAH: & (counts and folds up one finger at a time) one, two, three \\
\hline 44. & Karin: & $\begin{array}{l}\text { (in sync with the teacher, raises and lowers her index finger in time with the } \\
\text { counting) two, three (starts singing) the chicken... (another child runs across the } \\
\text { cloth, making the singing stop) }\end{array}$ \\
\hline 45. & SARAH: & $\begin{array}{l}\text { (points and counts again) one, two, three, the chicken in the egg... } \\
\text { (adjusts the cloth and looks at the teacher who counts, points in sync with her } \\
\text { counting, from two) }\end{array}$ \\
\hline
\end{tabular}


The content for learning emerging in this play is how to play the play in a specific manner. The teacher introduces the frame that constitutes the play. The child follows the initiated acts but then takes the initiative to repeat the play, following the same pattern (turns 42-46). She continues playing the same play on eight observed occasions, following the exact same framework and pattern of acts on her own.

\section{Learning How to Play}

In order to be able to play an occurrence of some kind (a contest or a visit to the doctor's) where several children participate, some social skills become necessary (and, thus, potentially contents for learning).

\section{Excerpt 8.7: The Way to Play out the Story}

\begin{tabular}{l|l|l}
\hline 35 & CIA: & $\begin{array}{l}\text { Once upon a time there were the three goats Gruff (with a dramatic voice, starts } \\
\text { creeping). Where were they going now? (Lisa and Peter climb up on the bridge) }\end{array}$ \\
\hline 36 & Peter: & You cannot go at the same time \\
\hline 37 & Lisa: & $\begin{array}{l}\text { But the little one goes first, then comes the middle goat and last comes the } \\
\text { biggest }\end{array}$ \\
\hline 38 & Child: & The little goat starts first \\
\hline 39 & CIA: & $\begin{array}{l}\text { Yes, if you're to play exactly as the tale is. But do you have to play exactly like } \\
\text { the tale is? }\end{array}$ \\
\hline 40 & Children: & Yees \\
\hline 41 & CIA: & Yes, okay, okay \\
\hline 42 & Lisa: & $\begin{array}{l}\text { Let's first go round a bit and graze and then we go up on the bridge (shows with } \\
\text { her arm how they can go)? }\end{array}$ \\
\hline 42 & Peter: & Noo \\
\hline 44 & Lisa: & Yees \\
\hline 45 & Peter: & Noo \\
\hline 46 & Lisa: & Yees \\
\hline 47 & CIA: & Hold on, hold on \\
\hline 48 & Peter: & Noo \\
\hline 49 & CIA: & $\begin{array}{l}\text { Stop, stop, stop. Do you know what, Lisa and Peter, if there is to be any play, } \\
\text { what is most important for it to become a play? }\end{array}$ \\
\hline 50 & Child: & Agreeing \\
\hline 51 & CIA: & Agreeing. Does it feel like you're agreeing now? \\
\hline 52 & Children: & No \\
\hline & &
\end{tabular}

Two learning contents emerge in the sequence represented by Excerpt 8.7: first, how a play based on a known story should be designed and performed (in terms of roles, order of occurrences, turns 35-38), and second, the skill to compromise and find a solution to how the story should precede that satisfies all the participants (turns 42-52). In the episode represented by this excerpt, there is not at this point 
temporarily sufficient intersubjectivity in order for the participants to go on with a joint activity (mutual play). The teacher enters and tries to support the children in handling this problem, which can be seen as one of many ways that teachers are important to children's play. The episode also shows how learning to play in preschool is inherently part of socialization practices: learning how to be with others. Learning the kinds of skills necessary for the latter are not separate from learning to play or learning in play. This excerpt is also illustrative of a known story framing play in a unflexible way for children; - according to the participating children (turn 40 , responding to the teacher's question in turn 39) - it has to be played "exactly like the tale is" (cf. Excerpt 6.3, turn 113).

\section{Developing Concepts as Part of the Play}

There is another category of contents that emerge when analyzing children's play. These contents of learning are phenomena that are explored as the goal of the play, commonly some novel concept. This seems to be most common among younger children, to whom many basic concepts relating to the surrounding world are novel, but this can also be observed among older preschool children, for example when playing with letters and words. Excerpt 8.8a is taken from a longer episode of kitchen play, where three toddlers and one teacher share imaginary milk and ice cream.

\section{Excerpt 8.8a: More Milk from the Jug}

\begin{tabular}{l|l|l}
\hline 59. & Said: & $\begin{array}{l}\text { (picks mugs from a table and put them on another table, pretends to pour from a } \\
\text { jug to a glass) }\end{array}$ \\
\hline 60. & Tim: & (takes out something from a box and gives it to MIA) \\
\hline 61. & MIA: & $\begin{array}{l}\text { I can take it (takes what Tim gives her and puts it in her pocket) it's alright, I can } \\
\text { take it }\end{array}$ \\
\hline 62. & Said: & (pretends to pour from jug to glass) \\
\hline 63. & Said: & Here's milk \\
\hline 64. & MIA: & What do you bring? \\
\hline 65. & Said: & Here's milk \\
\hline 66. & MIA: & Do you come with milk? \\
\hline 67. & Said: & Yes \\
\hline 68. & MIA: & Ooh, thanks \\
\hline 69. & Tim: & (inaudible) \\
\hline 70. & Said: & (pretends to pour from jug to glass) \\
\hline 71. & Tim: & (goes to pour from the same jug to his cup, but is hindered by Said) \\
\hline 72. & Said: & I can \\
\hline 73. & Tim: & (holds his cup to the teacher. Said follows with the jug) \\
\hline 74. & MIA: & Edvin wants more milk (to Said) okay? \\
\hline 75. & Said: & Okay (goes to Edvin and pretends to pour) \\
\hline
\end{tabular}




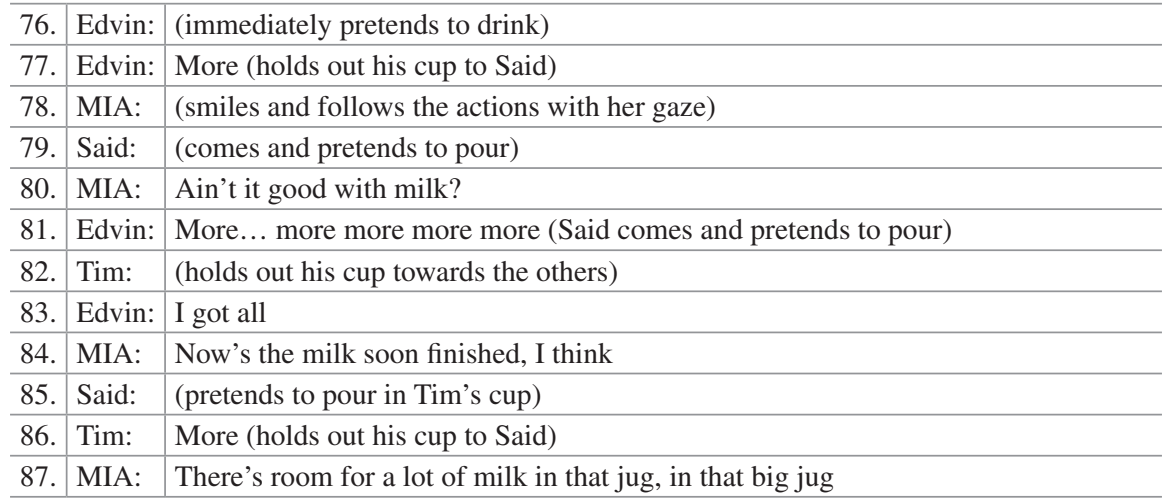

In turn 87 , something happens that disrupts the play, which up until then has followed the same pattern. The children and the teacher have drunk milk from their cups, over and over again, with more milk added by Said from the jug. The teacher then states that the jug seems to contain quite a lot of milk. She thereby directs attention towards the amount of (imaginary) milk that has been poured from the jug to the cups. This seemingly ordinary statement does however point out something specific about the relationship between the jug and the cups and triggers a change in the child's way of handling the containers:

\section{Excerpt 8.8b: From Container to Jug to Cup}

\begin{tabular}{l|l|l}
\hline 88. & Said: & $\begin{array}{l}\text { No, here (goes to the other table where there's some other things, pretends to } \\
\text { pour more milk from a carton) }\end{array}$ \\
\hline 89. & MIA: & (inaudible) look you can fill up over there!... wow \\
\hline 90. & Said: & (pretends to pour in Tim's cup) \\
\hline 91. & Tim: & (shows his cup) \\
\hline 92. & MIA: & It's like a milk machine, it looks like \\
\hline 93. & Said: & (puts the jug upside down over a glass) look (points)! \\
\hline 94. & Tim: & Looks (points)! \\
\hline 95. & MIA \& & (inaudible) \\
\hline 96. & Edvin: & \\
\hline 97. & Sim: & (tries to help Said) \\
\hline 98. & Edvin: & The ice cream is in there (to MIA) \\
\hline 99. & MIA: & Is it in there? \\
\hline 100. & Tim: & (goes to Said and holds out his cup. Said pretends to pour) \\
\hline 101. & MIA: & (inaudible to Edvin. Tim walks between the tables with his cup) \\
\hline 102. & MIA: & You haven't put it in yet? \\
\hline 103. & Tim: & More milk! (shows MIA his cup) \\
\hline 104. & MIA: & You got more milk \\
\hline 105. & Tim: & Yees \\
\hline 106. & MIA: & He had more there \\
\hline & &
\end{tabular}




\begin{tabular}{|c|c|c|}
\hline 107. & Said: & (pretends to pour from jug to glass) \\
\hline 108. & Tim: & More milk, I... \\
\hline 109. & Said: & $\begin{array}{l}\text { Not that one, not that one (takes something from Tim and pretends to pour } \\
\text { from a carton) that! }\end{array}$ \\
\hline 110. & Said: & (pretends to pour from jug to glass) \\
\hline 111. & MIA: & Now you've drunk lots of milk \\
\hline 112. & Tim: & (inaudible) \\
\hline 113. & Edvin: & Oh, the ice cream, it melts \\
\hline 114. & Tim: & $\begin{array}{l}\text { More, more milk! (hands the carton to MIA) I get more milk (makes fetching } \\
\text { movements with his hand, from the floor to the carton) }\end{array}$ \\
\hline 115. & MIA: & Oh, you can fill up like that \\
\hline 116. & Said: & No, it's in there (holds out the jug) there also, not... \\
\hline 117. & $\begin{array}{l}\text { Said and } \\
\text { Tim: }\end{array}$ & (hold the carton) \\
\hline 118. & MIA: & Watch it so it doesn't break, oh oh oh, carefully! \\
\hline 119. & Child: & (inaudible) \\
\hline 120. & MIA: & You cannot pull it, then it breaks (to Tim and Said) \\
\hline 121. & Tim: & I want it \\
\hline 122. & MIA: & $\begin{array}{l}\text { Wait, let's see... can you fill milk in this? (to Said) can you do that? Can you } \\
\text { fill milk in this? }\end{array}$ \\
\hline 123. & Said: & (goes with the carton to the other table) \\
\hline
\end{tabular}

Said immediately takes the new question about the amount of milk in the jug into account and explains that the milk in the jug comes from a larger container on the other table (turn 88). The play then continues in a more complex fashion, where the container also plays its role as providing milk to the jug and consequently to the cups. A seemingly simple play among toddlers is in this way extended by the teacher's comment on the amount of milk a jug may contain and the "milk-pouring" play continues. Tim (in turn 114) takes initiative to expand the play content. He was not allowed to use the box or the container that Said is in possession of, but Tim's act of filling up the larger container box gives him an important role and extends the concept they elaborate on in the play. The two last categories of content for learning in play have in common that the initiatives to expand or explore experiences are emerging mutually between teacher and children within play.

\section{Discussion}

We have here seen a number of contents of playing and learning being constituted in mutual activities. One thing that we can note is that there is much dialogue between the teacher and children in the play situations we have analysed, something earlier research on ECEC has pointed out as largely missing (e.g., Sylva, Roy, \& Painter, 1980; Siraj-Blatchford \& Manni, 2008). However, this is likely contingent 
on the fact that in the project we ask teachers to try to participate in, and make contributions to, play.

Clearly, what teachers decide to respond to in, or introduce into, these activities has consequences for what becomes the content of the play (see also Pramling $\&$ Pramling Samuelsson, 2010) and therefore also for what children can learn in interaction with the teacher and each other in these activities. Sometimes children are eager to be involved (see Excerpt 8.4) when the teacher takes the lead, and sometimes the very element of play is at risk of disappearing, that is, the as-if nature of such an activity, when teachers participate (see Excerpts 8.3a and 8.3b).

A premise for our reasoning is that there is always some kind of content constituted in communicative activities. What we have seen here is that it can vary between a single content for learning that is unrelated to what the play is about; in these cases, in our examples, always introduced by the teacher; towards learning the frame of a play; or contents for learning that emerge during play. Different contents are constituted in communication, for instance values, skills or knowledge that may be more or less specifically related to the goals of preschool curriculum. There are play activities in our data that do bring to the fore an academic content, some of which are discussed in this chapter (see Chaps. 9, 10, and 11, for examples analysed in depth), but content for learning in the observed play settings are often directed towards social skills.

\section{References}

Bäckman, K. (2015). Matematiskt gestaltande i förskolan [Mathematical gestalting in preschool]. Åbo, Finland: Åbo Akademi University.

Björklund, C. (2007). Hållpunkter för lärande. Småbarns möten med matematik [Critical conditions of learning - Toddlers encountering mathematics]. Åbo, Finland: Åbo Akademi University.

Björklund, C., Magnusson, M., \& Palmér, H. (2018). Teachers' involvement in children's mathematizing: Beyond dichotomization between play and teaching. European Early Childhood Education Research Journal, 26(4), 469-480.

Lundström, M. (2015). Förskolebarns strävanden att kommunicera matematik [Preschool children's attempts to communicate mathematics]. Göteborg, Sweden: Acta Universitatis Gothoburgensis.

Magnusson, M., \& Pramling, N. (2017). In 'Numberland': Play-based pedagogy in response to imaginative numeracy. International Journal of Early Years Education, 26(1), 24-41.

Piaget, J. (1951). The child's conception of the world (J. Tomlinson \& A. Tomlinson, Trans.). Savage, MD: Littlefield Adams. (Original work published 1926).

Pramling, N., \& Wallerstedt, C. (2009). Making musical sense: The multimodal nature of clarifying musical listening. Music Education Research, 11(2), 135-151.

Pramling, N., \& Pramling Samuelsson, I. (2010). Evolving activities and semiotic mediation in teacher-child interaction around simple objects. Educational \& Child Psychology, 27(4), 22-30.

Pramling, N., \& Säljö, R. (2015). The clinical interview: The child as a partner in conversation versus the child as an object of research. In S. Robinson \& S. Flannery Quinn (Eds.), The Routledge international handbook of young children's thinking and understanding (pp. 87-95). London, UK: Routledge. 
Siraj-Blatchford, I., \& Manni, L. (2008). Would you like to tidy up now?' An analysis of adult questioning in the English Foundation Stage. Early Years, 28(1), 5-22.

Sylva, K., Roy, C., \& Painter, M. (1980). Childwatching at playgroup and nursery school. Oxford, UK: Grant McIntyre.

Vygotsky, L. S. (1978). In M. Cole, V. John-Steiner, S. Scribner, \& E. Souberman (Eds.), Mind in society: The development of higher psychological processes. Cambridge, MA: Harvard University Press.

Open Access This chapter is licensed under the terms of the Creative Commons Attribution 4.0 International License (http://creativecommons.org/licenses/by/4.0/), which permits use, sharing, adaptation, distribution and reproduction in any medium or format, as long as you give appropriate credit to the original author(s) and the source, provide a link to the Creative Commons licence and indicate if changes were made.

The images or other third party material in this chapter are included in the chapter's Creative Commons licence, unless indicated otherwise in a credit line to the material. If material is not included in the chapter's Creative Commons licence and your intended use is not permitted by statutory regulation or exceeds the permitted use, you will need to obtain permission directly from the copyright holder.

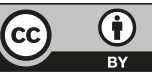

